\title{
THE DECLINE OF HUMAN CAPITAL IN UKRAINIAN EDUCATION AND SCIENCE: EXPERIENCE OF REVERSAL
}

\author{
Oksana Abreu Bastos \\ Kiev National University of Technologies and Design, Cherkassy, Ukraine \\ Vladyslav Koshulko \\ Karol Adamiecki University of Economics in Katowice, Katowice, Poland
}

() MESTE NGO

JEL category: I2, I21, I19, J2, J24

\begin{abstract}
Preservation and enhancement of the quality of education should be a priority in the development of any society. But, the Ukrainian higher education system has ceased to be competitive, and to date has continued to reduce in prestige. Ukrainian higher education diplomas are not recognized worldwide, in contrast to European and American diplomas. The vast majority of graduates are not competitive in the European labor market. 84\% of Ukrainian students do not associate their professional future with Ukraine. Wages in the Ukrainian education system over the years are unprecedentedly low compared with other countries. Corruption and bribery have penetrated into all areas of higher education of the country.

Today, the Ukrainian sciences are three times behind Germany, twice from Slovakia, Hungary, Estonia, Spain, and the Czech Republic, and are on level with Romania and Bulgaria.

So, these are the reasons why Ukraine continues losing their young people, "the golden gene pool" of the nation, and faces a "Brain Drain" of the country. What are the steps that must be taken in the Ukrainian system of education, to regain prestige and respect? Completely and permanently eradicate corruption and bribery from the higher educational institutions of Ukraine raise the wages of the teaching staff of the Ukrainian universities to the international level, etc.
\end{abstract}

\section{Keywords:}

human capital, higher education institutions, scientists, teachers, academics, development, wages, science and education, international scientific journals, universities

\begin{tabular}{|c|c|c|}
\hline & 1 & $\begin{array}{l}\text { ANALYSIS OF } \\
\text { COMPETITIVENESS THE } \\
\text { UKRAINIAN EDUCATION SYSTEM }\end{array}$ \\
\hline $\begin{array}{l}\text { The address of the author: } \\
\text { Oksana Abreu Bastos } \\
\text { 莑" abreubastos.oksana@gmail.com }\end{array}$ & & $\begin{array}{l}\text { ainian higher education degrees are } n \\
\text { ognized in the world, in contrast to th } \\
\text { opean model of diplomas. If, for example, }\end{array}$ \\
\hline
\end{tabular}


Brazil, the sixth world economy, part 180-million population with tertiary education is $7.9 \%$ (Terra, 2012), in Ukraine with 45 million people, $90 \%$ of citizens have secondary or higher education (Ukrainskaya sistema obrazovaniya, 2012). This fact indicates the quantity, not the quality of education in Ukraine.

What is the problem lack of competitiveness of the Ukrainian system of education, particularly higher education, compared to other education systems of the leading countries of the world? Perhaps the problem is that in the Ukraine in the system of higher education is not the accumulation of human capital? Categorically impossible, as in Ukraine today there are hundreds of institutions of higher education, where human capital is accumulated in the process of higher education. Why, then, is there not enough system of higher education? We believe that it lacks the quality of underinvestment in human capital.

The concept of "human capital" is not only the realization of the crucial role of human beings in the economic system of society, but also recognition of the need to invest in people, because capital is acquired and increased by investment (due to limitations of current consumption) and bring long-term economic impact.

Investments in human capital are any actions that improve their professional skills and productive capacities of man, and thus the performance of his work. Expenditures that enhance human performance can be seen as an investment, since operating costs are made with the expectation that they will be compensated for income in the future (Vasylchenko, Grinenko, Gryshnova, \& Kerb, 2005).

To date, the Ukrainian system of education is not competitive because the human capital of Ukrainian scientists, teachers and academics is not invested either by the state or by foreign educational foundations because of the low mobility of the faculty of education, or from the personal investment - because of meager wages. In view of this, the human capital of the Ukrainian science and education undergoes regression: the country going backwards.

\section{THE CURRENT STATE OF UKRAINIAN SCIENCE AND ITS FUTURE DEVELOPMENT}

Human capital development is inextricably linked to the development of science. However, according to D. Polozenko (2006, pp. 15-23), Ukrainian science is constantly experiencing "financial arrhythmia" - budget spending on science in 1992 was 2.2\%, in $1996-1.9 \% 1999$ $0.8 \%$ in $2002-0.9 \%, 2004-2.2 \%$.

In future periods, the situation has not improved in science. Analyze the dynamics of the financial sector "Science" from the State Budget of Ukraine for 2007-2011, Million UAH.

It is worth emphasizing that in fact the trend of decline in the share of the state budget on the science of GDP in 2007 and 2008, - $0.47 \%$ of GDP in $2009,-0.45 \%$ of GDP in $2010,-0.43 \%$ of GDP in $2011-0.38 \%$ of GDP. This is the lowest in the country over the last decade and the lowest rate among all European countries.

During the period of 1991-2011 years, Human resources science declined by more than three times. In 1991, the number of performers of scientific and technical work on the 1000 population of Ukraine was the first European country. Today the Ukrainian Science 3 times behind Germany, twice from Spain, Slovakia, Hungary, the Czech Republic, Estonia, while at Bulgaria and Romania.

Compared with 1991, the number of doctors and candidates engaged in scientific and technological activities, decreased by 8848 people (by $28 \%$ ) due to the fact that their total number is constantly increasing. Also, the number of students, graduate and doctoral students is increased by 2.5 times, but the quality of their training has deteriorated. Intellectual continuity of generations is at risk. (Oleskin, 2012)

Ukrainian legislation provides for government funding of scientific activity at the level of $1.7 \%$ of GDP, which should be done by the base and competitive program financing. (Polokhalo, 2011) As already noted, the actual funding is at $0.38 \%$ of GDP in 2011.

B. Danilishin and V. Kucenko, based on data from the International Labor Organization, say: 
"If, the country, in science spends less than $2 \%$ of GDP, begins the destruction not only of science but also the economy, and society in general." (Danilishin \& Kucenko, 2006)

In situations of chronic underfunding, Ukrainian science is on the brink of survival. With no objective opportunities for a full research, scientists have to settle for a so-called "scientific secondary".

In addition, in 2011, researchers NASU not receive additional pay for academic degrees and doctoral degrees. Senior Researcher PhD receives a monthly salary of salary $2417-2500$ UAH (300-350 USD) - these are the smallest salaries of scientists in the world.

Wages in Ukraine, including researchers, over the years cannot be a source of human capital investment, as unprecedented is low compared with other countries. (Koshul'ko \& Koshul'ko, 2012, pp. 146-153) That is where we can see the source of increasing levels of migration, which, according to the results of the independent World Bank, in 2010, Ukraine took $5^{\text {th }}$ place in the world after Mexico, India, Russia and China. (Ratha, Mohapatra, \& Silwal, 2011)

According to another independent study of German experts, Ukraine is among the ten countries with the poorest citizens. In 2011, the average Ukrainian property was 928 euros (not including money spent on the credits.) These data are published German insurance company «Allianz» in its latest "Report on the global wealth in 2012." Ukraine occupies $49^{\text {th }}$ place among 52 countries in the ranking by income citizens. (Ukrayina uvijshla do desyatky krayin z najbidnishymy hromadyanamy, 2012)

Wage level scientists significantly, and in the negative direction is different from the other groups. The key is that the level of income, in principle, does not allow them to solve their particular problems (housing, sanitation, etc.). According to statistics, in 2010, the salaries of scientists ( $R$ \& $D$ performers) increased by $1.4 \%$ to Rs 2535 (2218 UAH in 2009), almost at the level of wages of industrial workers (2580 Rs.), and well below the level of pay in the financial sphere (4601 Rs), as well as in a public administration (2747 $\mathrm{UAH})$. The issue of income inequality is the reason scientists their negative morale, and society with a sharp differentiation of incomes differs social instability, lack of strong incentives for professional growth, a significant degree of criminality of social relations, etc. No less urgent is the problem of logistics research, which requires significant financial resources to upgrade machinery and equipment. At the same time, the problem of underfunding for years cemented a number of other socio-economic and psychological problems. The most acute is a problem of housing for young scientists, health care facilities and the like. Low prestige of scientific labor and social protection of scientists had a negative impact on the completion of scientific institutions young, talented professionals. Such a lack of understanding that social, physical health scientists have a decisive influence on the level of their morale, creative thinking, creative scientific inspiration, is fatal to the country in the new global times for the economy, which should be based on knowledge. Therefore, crucial for scientists in Ukraine remains the problem of the transition from an existential level the own needs (security of existence, providing comfortable living conditions, etc.) to higher - social, spiritual. However, taking care of the problems of self-expression and success in science, as well as provide for themselves and their families with the necessary material means of subsistence, some scholars go abroad Ukraine. Although official statistics are not striking is considerable, but it clearly shows the trends, the realization of which is much more important. So, given the current state statistics, the most difficult period for the national scientific potential was the period 1991-1999., When went from Ukraine for permanent residence 268 doctors (including $40 \%$ in the technical area), who worked in perspective areas of mathematical analysis, solid state physics, semiconductor physics, structural mechanics, solid mechanics, surgery. (Mekh, 2012)

According to Ombudsman Ukraine, in the period from 1993 to 2003, 574 doctors and 907 candidates of science emigrated abroad. (Karpachova, 2003, pp. 14-15) (Karpachova, 2005, pp. 6-8) According to studies of O. Mekh (2012), most mass departure of scientists with a doctorate was in the 1990s. In the year 1996, one PhD left Ukraine every day. By the turn of the 
century the process slowed down, the total number of candidates who left in 2006 was 5 times less than in 1996 and in 2008 that number reached a minimum value. However, in 2009 2010 their number increased again. (Mekh, 2012)

Focused on the oligarchs, socio-economic and socio-political model of modern Ukraine pushes science to degradation. When a country is in the state of geopolitical uncertainty, this can cause severe consequences for its existence among super-rigidity global competition. (Polokhalo, 2011)

On the basis of the experience of developed countries (Lebedev \& Milenin, 1996), the basic principles of an effective system of direct government support in science (especially basic research) must be:

- In a careful and informed choice of priorities: there must be a clear system to choose the direction of support;

- In a variety of sources and methods of state support. There should be not one, but several sources of public resources for scientific and technological research;

- The selectivity and competition in the allocation of resources;

- In a democratic and transparent decision-making. Identification of priorities and the allocation of public resources should be controlled by scientific community.

Summarizing all the above, it can be said that the Ukrainian science degrades without proper funding, without any innovative development (e.g. techno-parks; Now in the USA, there are about 200 techno-parks, In Germany and the Netherlands - around 150, in the Ukraine - no one!) The Ukraine continues to be a raw materials appendage of other technologically powerful countries of the world. (Koshul'ko \& Koshul'ko, 2012) Today, in Ukraine is existing one case of creating a technology park under the auspices of one of the universities, but if the approach to funding research and education projects in the near future doesn't radically change - it will remain another try only.

\section{3 "COMPETITIVENESS" OF UKRAINIAN DIPLOMAS: WHO IS TO BLAME AND WHAT TO DO?}

As a result, regression ${ }^{1}$ science entails the destruction of education. Lack of funds for education from the state budget is offset by private investment, particularly by parents because education today came out of the scope of the traditional allocation of resources and become a big business. (Poplavskaya \& Poplawsky, 2002)

As already noted, the Ukrainian higher education diplomas are not recognized almost everywhere, in contrast to the diplomas of European and American style.

In recent years, the quality of higher education in Ukraine has decreased to its lowest level. The vast majority of graduates are not competitive on the European labor market. Therefore, every year only increases the number of people wishing to study abroad. Naturally, after the formation of the "gold" gene pool of the Ukrainian nation will forever remain outside the country.

According to international research, "Students the image of the future", held in 2011 Gorshenin Institute in Ukraine, Russia, Kazakhstan and Poland, the homeland want to study $15.5 \%$ of the Ukrainian youth, at a time when $72.3 \%$ of Russians and $65,9 \%$ of Poles are planning to pursue higher education in the country. (Omel'chenko, 2011)

Today, $80 \%$ of the students dream of Ukraine exchange for work abroad. Most students of Ukrainian universities do not associate their professional future with Ukraine. According to the Ukrainian-Polish sociological research, more than $80 \%$ of Ukraine has the objective to work abroad. (Omel'chenko, 2011)

In Ukraine, until recently, none of the higher educational institutions were represented in the world rankings of universities, except in the Webometrics.info rankings, where in the year 2012 the "most successful" Ukrainian school was on $713^{\text {th }}$ place. On the same list, in the year 2013, the most successful Ukrainian National

\footnotetext{
${ }^{1}$ Regression - from Lat. Regressus - return, the

reverse movement
} 
Pedagogical University MP Dragomanova took $80^{\text {th }}$ place. (Ranking web of universities, 2013)

As for the two most prestigious international rankings, Shanghai ranking (ARWU, 2012) and the rating of "Times" (Times, 2012), the Ukrainian universities are not available to all.

Corruption and bribery have penetrated into all areas of higher education, is ignoring the "norm." Investing in public schools learning process (the upgrade logistics - repairs, furniture, books to pay for the work of cleaners and security guards of educational institutions) have long been laid on the shoulders of parents. As noted, "Education today came out of the scope of the traditional allocation of resources and become a big business." (Poplavskaya \& Poplawsky, 2002)

\section{CONCLUSIONS}

What are the steps needed to take the Ukrainian system of education to regain the prestige and respect, and human capital - the ability to develop?

Authors strongly believe that if the Ukrainian universities wish to gain competitiveness and prestige, and the human capital of the faculty gain the ability to replicate and accumulate, they must:

- Completely and permanently eradicate corruption and bribery, which have penetrated into all areas of higher educational institutions of Ukraine, first of all, due to the extreme plight of Ukrainian scientists and professors through low wages and poor quality of life:

- To raise the wages of the teaching staff to the international level (for example, today, $\mathrm{PhD}$, assistant professor in the Ukraine receives salary of $350-400$ USD, at a time when Poland teacher with a Master's Degree and a post receives wages of 2700 3000 PLN (more than 1000 USD); in Turkey - from 1000 USD and above. A scientist with a salary of 350 - 400 USD cannot have a competitive human capital! Thus, the higher wages of teachers and scientists to meet international standards for scientists and educators can meet all the needs of the community and they play in and the accumulation of human capital;

- To promote and finance the publication of Ukrainian researchers in international scientific journals, study tour to promote Ukrainian teachers, study and implementation of international experience in Ukrainian universities;

- To introduce a requirement for teachers of Ukrainian universities - knowledge of English, the language of international communication, and create the conditions for effective teaching of English teachers at universities. For example, this condition is required for all university professors in Turkey;

- To develop digital libraries, Englishlanguage sites of universities, international Internet conference, exchange of students and teachers;

- Actively locate studies of university teachers on the sites, which will lead to more productive work, the growth of informal contacts and researchers from different universities from different countries, which will undoubtedly have a positive impact not only the reputation of the universities, but also in their places in the global rankings;

- Introduce and actively promote not formal, but really needed the national economy scientific topics that can be implemented in practice. In this direction, is to borrow the experience of Brazilian Universities (holding, by the way, a leader in global education rankings!) That perform government contracts, to prepare examinations of national importance - for those wishing to join the public service in this country. Such examinations are transparent and accessible to every citizen of the country, thus preventing any manifestation of corruption in government offices. It is this system of government confirms the motto of Brazil: "Order and Progress." In our opinion, these are the steps to be taken in Ukraine, that science and education are to work for the development of the Ukrainian society, not existed in parallel to each other;

- Abandon the stereotypes of the Ukrainian education system prevailing until now, where to this day the practice of traditional, 
long-outdated, even the Soviet system of teaching, and the transition to the international practice of teaching students to actively use modern information technology to improve the quality of education, the effective distance education; (Novosti distancionnogo obuchenija, 2012)

- To determine the age limit for employment of key management positions in higher educational institutions of Ukraine - for rectors and vice-rectors - 60 years, for heads of departments - 65 years - for example, such restrictions adopted in higher education institutions in Poland. Such a requirement would increase the competitiveness of higher education and to promote the flow of talented young scientists to the management of higher education institutions in Ukraine - and thus will contribute to greater integration of the Ukrainian education system to international standards of quality in higher education;

- To establish contacts with international educational funds, (International education fund, 2012) for training opportunities, training, comprehensive development of Ukrainian educators, teachers and scientists to the accumulation of human capital to the level of foreign teachers. We are convinced just in case the teacher is formed and fully developed - it is able to teach a student!

- Initiate and create really necessary joint international research projects with foreign research laboratories, research centers, universities, Techno polis and technology parks, international research funds, (International Visegrad fund, 2012) and mutually beneficial to both sides of the scientific process, which could improve the material well-being and allowed to reproduce and accumulate quality human capital, so necessary Ukraine;
- Reduce the number of Ukrainian higher educational institutions to $3-4$, citing the principle of educational quality, not quantity. In this case, the main goal of the Ministry of Education and Science, Youth and Sports of Ukraine should be to preserve the quality of the human capital of Ukrainian scientists and teaching staff of higher education institutions, and not a complete "destruction", as it happens. Otherwise, illconsidered actions of officials may provoke a new wave of intellectual migration from Ukraine, which is fraught with irreversible consequences for science, education, and, ultimately, for the Ukrainian society as a whole;

- Maximum release Ukrainian academics from a huge amount of paper, a primitive activity that kills "creative freedom", distracting them from everywhere possible to "create" - to create something new, creative - training courses, tutorials, new areas of research, and so etc. This will not only give the opportunity to develop human capital as scientists and academics, but also in time saves Ukrainian science and education of plagiarism that pervades the entire Ukrainian system of education and science. Overseas teachers of universities mostly taught by them by lectures, new items - in Ukraine through "paper bureaucracy" teachers are not able to be creative - just play the borrowed material from different sources;

- To overcome gender inequality in higher education and science by creating the conditions for the opportunities for women to academic degrees, positions in universities and research centers, thereby bringing Ukraine closer to the international standards of human rights and freedoms.

\section{Works Cited}

Anon. (2012). International education fund. Retrieved from International education fund: http://www. iefund.org.uk/

Anon. (2012). International Visegrad fund. Retrieved from Visegrad fund: http://visegradfund.org/about/

Anon. (2012). Novosti distancionnogo obuchenija. Retrieved from Nezavisimaja zhizn' molodyh invalidov: http://www.independentfor.com/dstlnews.html 
Anon. (2012). Ukrainskaya sistema obrazovaniya. Retrieved 01 06, 2013, from See you in Ukraine: http://see-you.in.ua/ru/page/ukrainskaya-sistema-obrazovaniya

Anon. (2012, 09 20). Ukrayina uvijshla do desyatky krayin z najbidnishymy hromadyanamy. Retrieved from TSN Vrazhae: http://tsn.ua/groshi/ukrayina-vviyshla-do-desyatki-krayin-z-naybidnishimigromadyanami.html

Anon. (2013, 03 01). Ranking web of universities. Retrieved from Webometrics: http://www.webometrics.info/en/Europe/Ukraine?sort=asc\&order=Presence\%20Rank\%2A

ARWU. (2012). Academic ranking of world universities - 2012. Retrieved from Academic ranking of world universities: http://www.shanghairanking.com/ARWU2012.html

Danilishin, B., \& Kucenko, V. (2006). Intelektual'ni resursi v ekonomichnomu zrostanni: shljahi polipshennja ïh vikoristannja Ministers. Ekonomika Ukraini(1), 71-80. Retrieved 2013

Karpachova, N. (2003). State of preserving and protecting the rights of Ukrainian citizens abroad. Holos Ukrayini(72), 14-15.

Karpachova, N. (2005). The Annual Report on the state of human rights and liberties' compliance and protection in Ukraine. Holos Ukrayiny(133), 6-8.

Koshul'ko, O., \& Koshul'ko, V. (2012). Human capital in the context of international relations: state and prospects. Proceedings Conference accounting for intellectual capital: a look into the future, (pp. 146-153). Kharkov.

Koshul'ko, O., \& Koshul'ko, V. (2012). Human capital in Ukraine: how we do not value what we have. LAP LAMBERT Academic Publishing, 180.

Lebedev, S., \& Milenin, S. (1996). Krizis Rossijskoj nauki i puti vyhoda iz nego. Sociologicheskie issledovanija, 122-129. Retrieved from ESM portal: http://ecsocman.hse.ru/data/707/150/1217/016Lebedev.pdf

Mekh, O. (2012, 03 05). Vitchyznyanyj naukovyj potencial: dynamika finansovo-kadrovyx peretvoren". Retrieved from Research Club: http://www.researchclub.com.ua/jornal/219

Oleskin, A. G. (2012). Analiz finansuvannja vishoj osviti v Ukraini. Visnik Universitetu bankivs'koï spravi Nacional'nogo banku Ukraïni, 13(1), 120-122. Retrieved 01 06, 2013, from http://archive.nbuv.gov.ua/portal/Soc_Gum/VUbsNbU/2012_1/12_1_25.pdf

Omel'chenko, V. (2011, 04 09). Studenty - Obraz budushchego. Retrieved from Gorshenin Institute: http://institute.gorshenin.ua/annuals/5_studenti_obraz_budushchego.html

Polokhalo, V. (2011, 04 27). Uryad oligarhv ta zubognnya vtchiznyano nauki. Ukrainska pravda. Retrieved from http://www.ukrrudprom.ua/digest/Uryad_olgarhv_ta_zubognnya_vtchiznyano_nauki.html?print

Polozenko, D. (2006). Budget expenditures on human capital development. Finance of Ukraine(4), 1523.

Poplavskaya, J., \& Poplawsky, B. (2002). Economic and philosophical aspects of human capital. Bulletin of the Ukrainian NAS(12), 14-21.

Ratha, D., Mohapatra, S., \& Silwal, A. (2011). Migration and Remittances Factbook 2011. Retrieved from The World Bank:

http://siteresources.worldbank.org/INTPROSPECTS/Resources/3349341199807908806/Ukraine.pdf

Terra. (2012, 04 27). Mais brasileiros concluem faculdade: percentual subiu de 4,4\% para 7,9\%. Retrieved 01 06, 2013, from Terra: http://noticias.terra.com.br/brasil/mais-brasileirosconcluem-faculdade-percentual-subiu-de-44-para79,d4cbdc840f0da310VgnCLD200000bbcceb0aRCRD.html

Times. (2012). The world university rankings. Retrieved from Times higher education: http://www.timeshighereducation.co.uk/world-university-rankings/2011-12/worldranking/range/351-400 
Vasylchenko, V., Grinenko, A., Gryshnova, O., \& Kerb, L. (2005). Labour resources management. Kyiv: Kyiv National Economics University.

Received for publication: $\quad 27.01 .2013$

Accepted for publication: $\quad$ 29.03.2013

\section{How to cite this article?}

Style - APA Sixth Edition:

Bastos, O. A., \& Koshulko, V. (2013, 07 15). The decline of human capital in Ukrainian education and science: experience of reversal. (Z. Čekerevac, Ed.) MEST Journal, 1(2), 106-113. doi:10.12709/mest.01.01.02.10

Style - Chicago Fifteenth Edition:

Bastos, Oksana Abreu, and Vladyslav Koshulko. "The decline of human capital in Ukrainian education and science: experience of reversal." Edited by Zoran Čekerevac. MEST Journal (MESTE) 1 , no. 2 (07 2013): 106-113.

Style - GOST Name Sort:

Bastos Oksana Abreu and Koshulko Vladyslav The decline of human capital in Ukrainian education and science: experience of reversal [Journal] = Human capital in Ukrainian education and science // MEST Journal / ed. Čekerevac Zoran. - Belgrade : MESTE, 07 15, 2013. - 2 : Vol. 1. - pp. 106-113. - ISSN 2334-7058 (Online); ISSN 2334-7171.

Style - Harvard Anglia:

Bastos, O. A. \& Koshulko, V., 2013. The decline of human capital in Ukrainian education and science: experience of reversal. MEST Journal, 15 07, 1(2), pp. 106-113.

Style - ISO 690 Numerical Reference:

The decline of human capital in Ukrainian education and science: experience of reversal. Bastos,

Oksana Abreu and Koshulko, Vladyslav. [ed.] Zoran Čekerevac. 2, Belgrade : MESTE, 07 15, 2013, MEST Journal, Vol. 1, pp. 106-113. ISSN 2334-7058 (Online); ISSN 2334-7171. 